\title{
Perspectives on protective promotion as a remedy to unfair labour practices
}

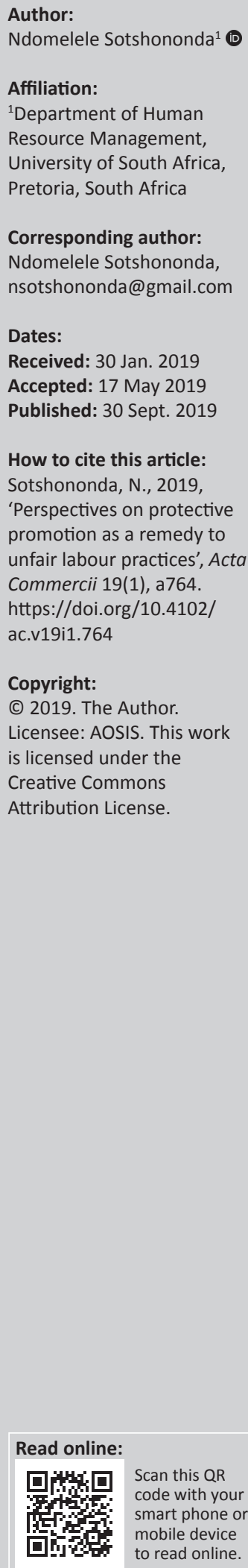

Orientation: The article focuses on the appropriateness of protective promotion as a remedy to unfair labour practices in relation to promotions.

Research purpose: To determine the reasons for which the labour courts accept or reject protective promotion as a remedy to unfair labour practice in relation to promotions.

Motivation for the study: The use of protective promotion, particularly in the public sector, is still controversial and subject to the approval of the labour courts.

Research design, approach and method: Content analysis approach was used as a method of conducting this research. The sample of 10 case laws were carefully selected from the labour courts websites focusing on the issue being studied. These case laws were selected based on their authenticity, relevance and credibility.

Main findings: It is evident from the arguments made by the courts regarding protective promotion that it should only be considered when there is enough evidence showing that the applicant was the best candidate for the position and would have been appointed had it not been for the employer's unfairness.

Practical/managerial implication: The outcomes of the article can be used as a guide for human resource practitioners and employers to be more careful about the consequences of unfair labour practices related to promotion, especially when an employee can prove that he or she deserved to be promoted. This also serves as a caution to arbitration commissioners to tread carefully when granting protective promotion.

Contribution/value-add: This article presents original research focusing specifically on the appropriateness of protective promotion and contributes to the existing body of knowledge about unfair labour practices in relation to promotions.

Keywords: Unfair Labour Practice; Promotion; Protective Promotion; Remedies; Appropriateness.

\section{Introduction}

Protective promotion is a form of a relief or remedy that is normally granted in a situation where an employee's opportunity to be promoted has been jeopardised by the employer's unfairness in decision-making (Odeku 2013:873). In such situations, if the complainant can provide compelling evidence showing that he or she was the best candidate for the job, he or she would then be given the salary and all the benefits attached to the position without necessarily occupying the position (Basson et al. 2009:198, 202). This kind of remedy to a promotion dispute is often used in the public sector; however, only a few cases concerning protective promotion succeed the review and appeal processes.

Promotion is defined as the advancement of an employee from one job to another on different levels and scales within the organisation (Heathfield 2018; Odeku \& Nevondwe 2012:266). Promotion is, therefore, considered to have taken place if there is a change in the status of the employee, along with an increase in responsibilities and salary, after he or she has moved from one job to another (Heathfield 2018).

The relationship between the employer and employee is governed by many legislative prescripts including the Labour Relations Act No. 66 of 1995 (hereinafter referred to as 'LRA'). To ensure fair and harmonious relationship between the parties in an employment relationship, the LRA provides guidelines on how appointments and promotions should be managed. To this end, Section 186(2)(a) of the LRA defines unfair labour practices as any act or omission that occurs in the employment relationship due to the employer's decision regarding the promotion process, 
the demotion of an employee and provisions relating to benefits and training development. The act also provides various remedies to an employee whose promotion opportunity was denied through unfairness in the process (LRA 1995).

Organisational justice plays an essential role in the employment relationship. Organisational justice is defined based on how employees within an organisation view management decisions in terms of the following dimensions: resource distribution among employees and departments, interaction between the organisational management and employees, and finally the procedures followed in reaching decisions (Cropanzano \& Molina 2015:380; Yean \& Yusof 2016:798). Should employees perceive the way resources are distributed and the way management communicates with them negatively, that could impact adversely on the organisation. Negative perceptions can result in poor work performance, tension among employees and towards the management and breach of employee trust and organisational commitment (Yean \& Yusof 2016:798). Procedural justice resonates well with this article as it refers to the fairness of the management decisions, organisational policies and procedures that influence decision-making. It is within this premise that employers' decision to promote or not to promote employees could also be linked to procedural justice. It is therefore necessary for the organisational management to have all the necessary skills and competencies needed to make sound and fair decisions as perceived fairness in decision-making can counter-influence the consequences of perceived unfairness (Yean \& Yusof 2016:800-802).

\section{Remedies for unfair labour practices relating to promotion}

It is an accepted requirement that an employment relationship must exist between an employer and an employee for the unfair labour practice dispute, specifically relating to promotion, to arise. This enables presiding officers or commissioners to conclude and make a fair decision based on the relevant facts. The complainant must be able to prove, beyond doubt, that he or she was the best candidate for the job (Basson et al. 2009:202). Generally, should an employee or group of employees posit that they have been unfairly treated, they have the right to refer the matter to a bargaining council or to the Commission for Conciliation, Mediation, and Arbitration (2015; hereinafter referred to as the 'CCMA'). This referral should be done within 90 days of realising the unfair act or conduct by an employer; however, this timeframe is not exhaustive. Like any other disputes, should one of the parties not be satisfied with the outcomes of the CCMA, such party may refer the matter to the Labour Court (hereinafter referred to as the ' $\mathrm{LC}^{\prime}$ ') to have the CCMA outcome reviewed (Du Toit et al. 2015:576).

In this context, Section 193(4) of the LRA allows arbitrators some form of discretion by explicitly stating that arbitrators may determine any unfair labour practice dispute before them (arbitrators) on terms that are regarded as reasonable
(Du Toit et al. 2015:576,577; Grogan 2014:104). These terms include compensation, which is limited to 12 (twelve) months. However, it is also permissible for arbitrators to grant protective promotion as a remedy to an aggrieved employee, who has been denied opportunities unfairly (Grogan 2014:105). The Public Service Commission Staff Code permits a commissioner to grant such awards, provided there is enough evidence to prove unfairness from an employer's proceeding.

\section{The issue of joinder in promotion disputes}

In terms of Rule no. 26 (1) of the CCMA, the commissioner has the powers to join any person whose interests may be affected by the outcomes of the proceeding (CCMA Rules 2015:18). The Labour Appeal Court (hereinafter referred to as the 'LAC') stated that it is necessary and important to join a successful candidate in the proceedings of the case from the beginning, regardless of the relief sought (PSA v Department of Justice \& Others 2004: para 39). This caution is based on the possibility of dethroning a successful candidate should his or her promotion be found unfair and biased. However, it is very rare to have such a decision adopted by the court. Therefore, to avoid unnecessary referrals, it is better to have the successful candidate joined in the matter so that he or she can be given the opportunity to raise his or her concerns, as they are regarded as the unsuitable candidates or wrong appointees for the position.

However, in a similar case, which involved Gordon v Department of Health: KwaZulu-Natal (2008:para 9, 10), the Supreme Court of Appeal (hereinafter referred to as the 'SCA') adopted a different approach, where it argued that a successful candidate needs not to be joined in the proceeding if the relief sought poses no threat to him or her. Grogan (2014:105) also share the same ideology concerning the joinder issue.

\section{Cases in favour of protective promotion}

This section contains paragraphs highlighting some of the case laws where the LC concurred with the arbitrators' decision to grant protective promotion. In the case of the Minister of Safety and Security v Safety and Security Sectoral Bargaining Council (2010:para 1, 2), the aggrieved employee was dissatisfied with the Minister of Safety and Security's decision for not promoting him to the rank of superintendent. The employee referred the matter to relevant forum, and the arbitrator found the Minister to have committed unfair labour practice by not promoting the aggrieved complainant. Consequent to that, the arbitrator granted protective promotion as the relief. Against this, the Minister of Safety and Security applied to the LC to have the arbitrator's award reviewed, which was in favour of the aggrieved employee.

The LC concurred with the arbitrator's decision to grant protective promotion and evaluated the arbitrator's decision 
as fair. Further to this, the LC clearly stated that the arbitrator had not intended to unseat the successfully appointed candidate. In demonstrating its fairness, the court argued that the arbitrator's focal point was to provide justifiable relief to the aggrieved employee. Consequent to that, the court turned down the Minister's request to overturn the arbitrator's award (Minister of Safety and Security v Safety and Security Sectoral Bargaining Council 2010:para 25, 28).

It also happened in SA Municipal Workers Union $\mathrm{v}$ Emalahleni Local Municipal (2011:para 2, 3, 21, 29-30), where the applicant applied to the advertised position he acted in for 2 years, and he was ranked as the second-best candidate. After the municipality decided not to appoint the first-ranked candidate, the position was re-advertised, and this contradicted the municipal policy which stated that if the candidate ranked number one cannot be appointed for any reasons, the second-best candidate should be appointed. And this clause was not adhered to. As a result, the aggrieved employee referred the matter to the relevant forum for assistance, and the arbitrator dismissed the claim of unfair labour practice arguing that the applicant had waived its right to do so by participating in the second round of interviews. The aggrieved employee challenged the arbitrator's decision in the LC, and the arbitrator's decision was reversed. The LC further stated that the employee's decision to participate in the second round of interviews did not constitute any relinquishing of his unhappiness (SA Municipal Workers Union v Emalahleni Local Municipal 2011: para 2, 3 , 21, 29-30). The LC argued that issuing an award that forces the employer to promote the complainant to an already occupied position would never be practical. This necessitated the LC to issue a protective promotion as a form of relief to ensure that the complainant gets all the benefits linked to the contested position (SAMunicipal Workers Union v Emalahleni Local Municipal 2011:para 29-30).

In De Nysschen v General Public Service Sectoral Bargaining Council (2006: para 1-4, 8), an employee felt aggrieved with the employer's decision not to promote her after she acted in the position for a period of 4 years. As it is best to recruit from a pool of qualified applicants, the position was externally advertised, and the applicant applied; however, she was unsuccessful. Even though her experience and good record compelled the selection committee to put her name forward for a promotion appointment, the employer overturned this decision and decided to appoint another job applicant.

Against this, the applicant regarded her non-appointment as an unfair labour practice, and the matter was referred to the relevant forum for arbitration. However, from the arbitrator's position, the applicant failed to prove the unfairness hurdle. Through continuous referrals and appeals, the matter landed in the LC for adjudication. In determining the matter, the court found the employer at fault and regarded its actions as one that constituted an unfair labour practice. The absence of concrete justification validating that the correct procedure was followed also contributed to the court decision.
In concluding remarks, the court held that the employer's decision not to appoint the recommended applicant was procedurally unfair and in contradiction with the appointment criteria that referred to career path, retention of skilled employees, staff motivation and continuity. Based on the evidence led by the applicant, the court reached the decision that the applicant should be appointed and remunerated as if she was successful in her application (De Nysschen v General Public Service Sectoral Bargaining Council 2006:11, 13, 14, 24, 25).

Another case where an employee was not promoted despite meeting all the requirements was the City of Tshwane Metropolitan Council v South African Local Bargaining Council (2011:para 1, 6-9 [of the introduction], 4 [of the arbitrator's findings]). The employer advertised the position of Managing Engineer: Energy Management, and the position was given to a less-qualified person on the basis of employment equity targets, even though there was no employment equity plan in place to justify this. The arbitrator noted this flaw among others and referred to it in concluding the award. As is the procedure, the aggrieved employee referred the matter to the relevant forums, and it was decided by the arbitrator in his favour. The arbitrator ordered the employer to promote the aggrieved employee to the actual position, and this was one of the grounds on which the employer requested the LC to review the arbitrator's decision.

The LC had to exercise its authority and reverse some parts of the arbitrator's decision, where the employer was ordered to promote an aggrieved employee to the actual position. The LC looked at the possibilities and practicability of such order and concluded that it was not viable, as the position in dispute was occupied already. Due to this, the LC felt that it was necessary to replace the arbitrator's award about promoting the aggrieved employee and made an order that the employee had to be remunerated according to the position he was denied promotion for (City of Tshwane $\mathrm{v}$ South African Local Bargaining Council 2011:para 28).

\section{Cases against protective promotion}

In circumstances where an employee has proven beyond doubt that his or her opportunity to be promoted was thwarted due to unfair proceedings during the promotion process and, subsequent to that, he or she missed the opportunity to advance his or her career, the protective promotion would then be awarded. However, it is important to note that employers would probably challenge these kinds of awards as they incur cost on the employer's side. Such cost includes having to promote an employee to a position that is already occupied by another candidate (which is what the court referred to it as impractical [SA Municipal Workers Union v Emalahleni Local Municipal 2011:para 29, 30]), or to have an employee granted the protective promotion by the arbitrator or the LC which requires the employer to give the employee the salary and benefits attached to the position he would have received had he been promoted. 
In the case between the Minister of Safety and Security v Safety and Security Sectoral Bargaining Council (2008:para 4, $6,7,17)$, an employee filed a grievance against the employer for not promoting her to the position of superintendent. The selection panel recommended a successful candidate based on managerial experience, equity targets and the performance scores from the interview. The matter went to arbitration, and the protective promotion award was granted. The employer viewed the award granted by the arbitrator as inappropriate and challenged it through the LC. The LC drew its attention among other issues to the notion of nonjoinder of the successful candidate to the case proceedings. The LC's cause of disagreement was based on the possible impact the hearing outcomes may have on the successful candidate. Among other issues, the LC stated that protective promotion could affect and tarnish the individual's integrity, status and competency. Against this backdrop, the LC concurred with the Minister's view that the arbitrator had blundered, and the award was inappropriate (Minister of Safety and Security v Safety and Security Sectoral Bargaining Council 2008:para 11, 24-29).

It was also observed in KwaDukuza Municipality v SALGBC (2009:para 5, 6, 7, 9-16), where an aggrieved employee felt an opportunity had been denied to him to present his candidature by the concerned municipality. This came after the municipality decided to fill some positions without advertising them as required by the collective agreement. According to the aggrieved employee, those positions were in the managerial band, and therefore they should have been advertised. However, the municipality representative raised various arguments in support of the decision not to advertise the posts. Among other issues, the employer argued that the rationale behind not advertising the posts was to avoid retrenching employees who have been acting in those positions. The arbitrator concluded that protective promotion should be granted to the disappointed employees as a form of relief. The employer challenged the arbitrator's decision through the LC, contesting its reasonableness. In its assessment, the LC overruled the protective promotion award and granted a compensation order equivalent to 5 months. The LC held that it would only be necessary to grant a protective promotion, if the applicant proved that he or she suffered the actual loss.

The appropriateness of a protective promotion was also questioned in Noonan v Safety \& Security Sectoral Bargaining Council (2012:para 1, 2, 5, 10, 47, 49). The aggrieved employee referred the matter to the relevant forums, seeking protection from what he regarded as unfair labour practice relating to promotion. This came after the South African Police Service did not appoint the aggrieved employee to the superintendent position. The arbitration outcome turned out in favour of the employee. However, this was short-lived, as the employer had successfully challenged the reasonableness of the arbitrator's award in the LC. During the appeal, the LAC concurred with the LC decision to set aside the arbitrator's award and correctly argued that in the absence of evidence pointing that the disappointed employee would have been promoted if it were not for the unfairness of the employer, the protective promotion should not be considered as a form of relief. The LAC assessed the arbitrator's award, concluded that the employer's action indeed amounted to unfair labour practice and issued a compensation award.

In the case between Ncane $v$ Lyster No and Others (2017:para $1,20,38)$, the applicant was not promoted to the position of captain within the South African Police Service and referred the matter to the relevant forum seeking protective promotion as a relief but to no avail. Both the arbitrator and the LC, after careful consideration, felt that granting compensation award to the aggrieved employee would suffice. However, this was not enough as the aggrieved employee referred the matter to the LAC for better conclusion, which would have been protective promotion. The LAC also showed no mercy when it scrutinised the appropriateness of the protective promotion award. The LAC validated the decision taken by the LC to concur with the arbitrator's award (which rejected the applicant's allegation of unfair labour practice). Such a decision taken by the LC and the arbitrator was regarded by the LAC as a justifiable one, as there were no flaws from the employer's side. In addition, it was found that the employer had followed the procedure.

\section{Research methodology}

This article followed the content analysis approach, which is defined as a research tool used to investigate and analyse specific content in an orderly manner (Leedy \& Ormrod 2010:144). Therefore, content analysis was employed to analyse case laws, relevant documents and legislations relevant to the topic studied (Leedy \& Ormrod 2010:144). The main purpose of this article was to explore the extent to which the protective promotion, as a remedy to unfair labour relating to promotion, is accepted by the bargaining councils, CCMA commissioners and labour courts and to understand the reasons for its rejection in some cases. The research followed the interpretive approach, which explores the participants' perceptions on lived experience in a specific context (Hancock, Ockleford \& Windridge 2009:13). This was achieved through analysing the case laws, applicable legislations and other relevant documents to gain a clear understanding of how promotion process is managed in the workplace and, moreover, to identify the available remedies for aggrieved employees. The decision to select the South African public sector as a unit of analysis was for convenience purposes to access the case laws from the CCMA and labour court websites. Protective promotion, as a form of relief to unfair labour practice relating to promotion, is often used in the public sector. The case laws used in this article were selected based on their relevance and credibility.

\section{Conclusion}

The objective of this article was to explore and understand the appropriateness of protective promotion as a remedy for unfair labour practice and to discover the reasons for its 
rejection in some cases. The findings indicate that the only instance an arbitration commissioner can issue a protective promotion as a form of relief to disappointed employees is when there is enough evidence showing that such an employee could have been promoted if it was not for the unfairness of the employer's conduct during the promotion process. The only remedy that should be granted by the arbitration commissioners should be compensation, as provided for by section 194(1) of the LRA. Suffice it to say, compensation, as a form of relief to a dispute concerning unfair labour practice, should be considered as the best option. Originating from the discussion above, it becomes evident that arbitration commissioners should refrain from issuing protective promotion as a relief without having enough evidence showing that the aggrieved employee would have been appointed had it not been for the unfairness in the process. The evidence under the discussion of cases against protective promotion attests to this.

\section{Acknowledgements}

I would like to take this opportunity and thank the Acta Commercii Journal Editor and its entire staff members, including the reviewers, for the positive and constructive feedback and the opportunity they afforded me to submit the manuscript. Moreover, I would like to extend my gratitude to the University of South Africa's editing department for its assistance.

This article is based on the author's thesis for his Master's in Labour Law at the Nelson Mandela University, 2017, titled: 'Recent developments concerning the unfair labour practice relating to promotion' (unpublished Master's Thesis).

\section{Competing interests}

The author declares that no competing interests exist.

\section{Authors' contributions}

I declare that I am the sole author of this research article.

\section{Ethical considerations}

There was no ethical consideration due to the nature of the research approaches followed, which were content analysis and the use of the secondary data available in public domain (case laws from Google and Southern African Legal Information Institution); no ethical clearance was sought. This article followed all ethical standards for research without direct contact with human or animal subjects.

\section{Funding}

No funding was received for writing this article.

\section{Data availability statement}

Data sharing is not applicable to this article as no new data were created or analysed in this study.

\section{Disclaimer}

The views and opinions expressed in this article are those of the authors and do not necessarily reflect the official policy or position of any affiliated agency of the authors.

\section{References}

Basson, A.C., Christianson, M.A., Dekker, A., Garbers, C., Le Roux, P.A.K., Mischke, C. et al., 2009, Essential labour law, Labour Law Publications, Centurion.

City of Tshwane v South African Local Bargaining Council, 2011, 154 (LC).

Commission for Conciliation, Mediation and Arbitration, 2015, Rules for the conduct of proceeding before the Commission for Conciliation, Mediation and Arbitration, Regulation gazette No 10389. Pretoria, South Africa, viewed 11 March 2017 from https://www.ccma.org.za/Advice/Knowledge-Hub/Downloads/Rules-Legislation.

Cropanzano, R. \& Molina, A., 2015, 'Organisational justice', International Encyclopedia of the Social \& Behavioural Sciences 17(2), 379-338. https://doi.org/10.1016/ B978-0-08-097086-8.22033-3

De Nysschen v General Public Service Sectoral Bargaining Council, 2006, 96 (LC).

Du Toit, D., Godfrey, S., Cooper, C., Giles, G., Cohen, T., Conradie, B. et al., 2015, Labour relations law. A comprehensive guide, South Africa, LexisNexis.

Gordon v Department of Health: KwaZulu-Natal, 2008, 99 (SCA).

Grogan, J., 2014, Workplace Law, Juta \& Co, Claremont.

Hancock, B., Ockleford, E. \& Windridge, K., 2009, An introduction to qualitative research. The NIHR RDS EM/YH. Accessed: Hancock, B., Ockleford, E. \& Windridge, K., 2009. An introduction to qualitative research. The NIHR RDS EM/YH, viewed 17 April 2017, from http://www.rds-yh.nihr.ac.uk/wp-content/uploads/2013/05/5 April 2017, from http://www.rds-yh.nihr.ac.uk/wp-
Introduction-to-qualitative-research-2009.pdfb.

Heathfield, S.M., 2018, Learn about employee job promotions: A promotion elevates an employee's status and authority, viewed 10 November 2018, from https:// www.thebalancecareers.com/a-promotion-rewards-an-employee-for-workwWW.thebalancecareers.

KwaDukuza Municipality v SALGBC, 2009, 30 ILJ 356 (LC).

Labour Relations Act No. 66, 1995, Government Gazette No 16861.

Leedy, P.D. \& Ormrod, J.E., 2010, Practical research: planning and design, Pearson Education International, London.

Minister of Safety and Security v Safety and Security Sectoral Bargaining Council, 2008, 29 ILJ 688 (LC).

Minister of Safety and Security $v$ Safety and Security Sectoral Bargaining Council, 2010, 9 BLLR 965 (LC).

Ncane v Lyster No and others, 2017, (DA 27/15) 2017 ZALC 1.

Noonan v Safety \& Security Sectoral Bargaining Council, 2012, 9 BLLR 876 (LAC).

Odeku, K. \& Nevondwe, T., 2012, 'An overview of the contentious issues inherent in the promotional exercises in the workplace: Unfair labour practice re-visited', Pakistan Journal of Social Science 9(6), 266-274.

Odeku, O., 2013, 'Employee's perception of fairness of advancement: Implications for fair labour practices', Mediterranean Journal of Social Science 4(13), 867-874.

Public Service Association v Department of Justice and Others, 2004, 1 (LAC).

SA Municipal Workers Union v Emalahleni Local Municipality, 2011, 32 IL 2196 (LC).

Yean, T.F. \& Yusof, A.A., 2016, 'Organisational justice: A conceptual discussion', Procedia - Social and Behavioral Science, 219, 798-803. 3rd Global Conference on Business and Social Science-2015, GCBSS-201, 16-17 December. https://doi.org/ 10.1016/j.sbspro.2016.05.082 